\title{
Methods and Devices to Improve the Complex Human Being Functioning
}

\author{
Lucian T. MÂNDREA \\ Politehnica University of Bucharest, Bucharest, Romania \\ mandrea_lucian@hotmail.com,lucian.mandrea@upb.ro \\ Ioan I. CURTA \\ Transilvania University of Brașov, Brașov, Romania \\ icurta@yahoo.com \\ Marian N. VELCEA \\ University of Agronomic Sciences and Veterinary Medicine of Bucharest, Bucharest, Romania \\ marian.nicolae.velcea@gmail.com \\ Aurel I. CHIRILĂ \\ Politehnica University of Bucharest, Bucharest, Romania \\ aurel.chirila@gmail.com \\ Dragoș D. DEACONU \\ Politehnica University of Bucharest, Bucharest, Romania \\ dragos.deaconu@gmail.com
}

\begin{abstract}
The research presents in the first part of the article an original experiment recorded with a Thermo-Vision camera. It reveals the possibility of the human being to direct energy inside the own body but also to the exterior, to heal other persons. The subject, the first author of this article, sent continuously energy to his palms about five minutes. During this time the temperature of his hands grew with more than two degrees Celsius. The subject did not move at all. The energy can be thus directed then further to other persons in need, to help them recover their health. The second part of the article reveals how our inventions rewarded with a lot of gold medals and not only, the Bio-Chips Doctor Tech, can be used to improve the human general state. A very significant experiment is presented, where with the help of these devices the first author of the paper reached for example a general balance of $99.98 \%$. The third set of measurements presented in the article was made by means of three original types of Keshe devices. The first author of the article changed the energy at the level of the own third eye by means of the devices and could significantly improve his own state. These results are also presented in the last part of this article. For the second and the third sets of measurements, the general state of the person was evaluated by means of a Bio Well device. All the three previous types of the measurements are very original and suggestive for how we can help the others. The general purpose of the article is to show that we can do more in different ways for the others, about their health, their level of energy and their level of performance.
\end{abstract}

Keywords: The complex human being, the soul of the physical body, Bio-Chips devices, Keshe devices, the human energy level, the human energy centers, Bio Well device. 


\section{Introduction}

Our capacity to repair ourselves presented in the previous articles (Mândrea et al., 2015; Mândrea \& Torp, 2016; Mândrea \& Chirilă, 2017; Mândrea et al., 2018; Mândrea et al., 2019; Mândrea \& Curta, 2019) justifies obtaining very good results in terms of health and personal good physical and psychic state. All the past results showed what we can do for ourselves. In this article the authors wish to present what we can do for the others, in order to improve their general state, their health, their energy level and to improve their performances. Three types of original measurements were made.

During the first one we made a film with duration of more than five minutes. The subject sent energy to his palms and a Thermo-Vision camera recorded continuously this temperature. At the end we presented a graphic with the variation of the temperature in time.

The second set of measurements used the original Bio Chips invented by the authors. They show how useful these devices can be to improve the general condition of every person.

The third set of measurements is made by means of the Keshe devices which can also improve the general state of the subjects or patients.

\section{The Energetic Actions of the Soul}

Many films present different actions of entities after death, as the lights switched on, the different electric children toys turned on as well as the television turned on and so on. These are different actions which use energy after the death of the physical body. It is logical then that such actions can also be performed by the entity inside our body when we are alive.

Such an example is presented, when the first author of the article sent energy to his hands without moving at all. The energy is taken mainly from the zone of the abdomen, the place where the second main energy center of the body has its position. He succeeded therefore to rise the temperature of his palms with 2.2 degrees Celsius in about 5 minutes. A similar action was presented one year ago, at the level of the head, when the temperature grew with 3 Celsius degrees in about 5 minutes (Mândrea et al., 2019).

The energy sent at the level of the hands can be directed further away, outside the body, to make the others heal. The results of this experiment justify, for example, why Djuna Davitasvili could improve another persons' life. The Bio-healers will finally be happy because our experiment proves that healing the others by means of energy is possible.

In our case the energy was sent from the abdomen zone where the soul of the physical body has its equilibrium place (Mândrea et al., 2018). The detailed description of the phenomenon was presented by the first author of this article in his previous books (Mândrea, 2011; (Mândrea, 2014). It corresponds with the yogis' opinion which tells us that the abdomen is our place in the physical body. It also corresponds with the Karate fighters who declare that they take their energy from the "Hara" situated in the person's abdomen. The opinion of the first author of this article also corresponds with the opinion of the internationally recognized medium Lisa Williams as she explained in her book called "The survival of the soul" (Williams, 2011), as a third justification.

To understand well the complex functioning of the human being, not only the physical body must be considered (Newton, 2004, 2006). Otherwise, even great thinkers of the world are partially right. Taking into consideration the energy of the glowing orbs and the connection between the words the whole truth can be revealed. 
For example, Carl Gustav Jung was partially right when he spoke about the collective unconscious. It could be called unconscious because it is not related to usual perceptions and the reception of the information by the brain. Still, if we refer to the information captured during sleep by the soul which explores other zones and enters in contact with other entities, from where it obtains unavailable information in the usual way, then we cannot speak about the collective unconscious.

The same can be framed in the affirmation of Sigmund Freud, "The interpretation of the dreams is the noble way to know the unconscious activities of the mind". This affirmation is also partially possibly right. There are dreams which reflect only what happens with that person if the soul does not leave the body during the night. We can say again that if the soul makes an exterior incursion, the information obtained has nothing to do with the unconscious which keeps of a partial passivity of the brain during the night.

We consider that we can improve their opinion telling that the information can be obtained first at the level of our souls and then it can be transferred to the brain.

\section{Measurements and Results}

The first type of investigation was made using a Thermo-Vision Camera Fluke TI 300. During this experiment, the subject sent continuously energy to his palms. The thermal sensitivity of the camera is $\leq 0.05{ }^{\circ} \mathrm{C}$ at $30{ }^{\circ} \mathrm{C}$. The measurement domain is $-20{ }^{\circ} \mathrm{C}$ until $+650{ }^{\circ} \mathrm{C}$. The camera image resolution is $240 \times 180$ pixels (Fluke, 2013). A suggestive picture of the whole film is presented in Figure 1.

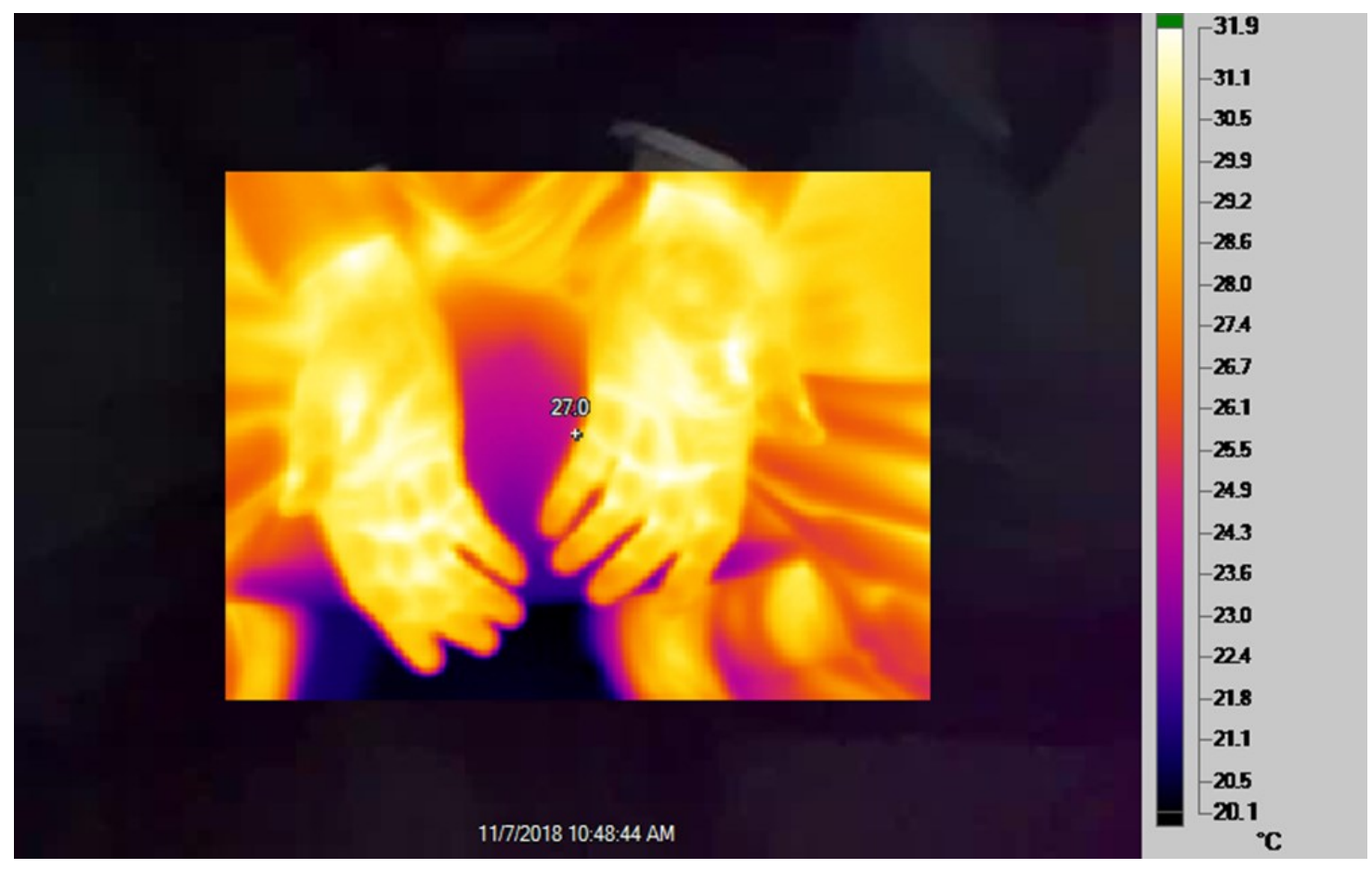

Figure 1. Global Thermo vision Camera state data, 2019 (The article's first author)

Source: Authors' own research. 
This presentation corresponds to a new original research, taking into account our publications in this domain of temperature registration (Mândrea et al., 2019; Mândrea et al., 2015; Mândrea, 2014).

The maximum temperature of the palms can be seen in the upper right part of the picture which in this case is $31.9^{\circ} \mathrm{C}$, at the moment when the picture from Figure 1 was taken.

During the experiment made by the first author of the article, the subject sent beams of energy to his palms which heated continuously, with $2.2{ }^{\circ} \mathrm{C}$ in 5 minutes and 6 seconds. The beams of energy were sent through the interior of the body.

A film was made and 12 significant frames were selected to design a graphic. The temperature rise was not as high as in the case of the head (Mândrea et al., 2019) because the palms radiant surface is very big compared with their volume. The palms maximum temperature variation of the subject in time can be seen in Figure 2.

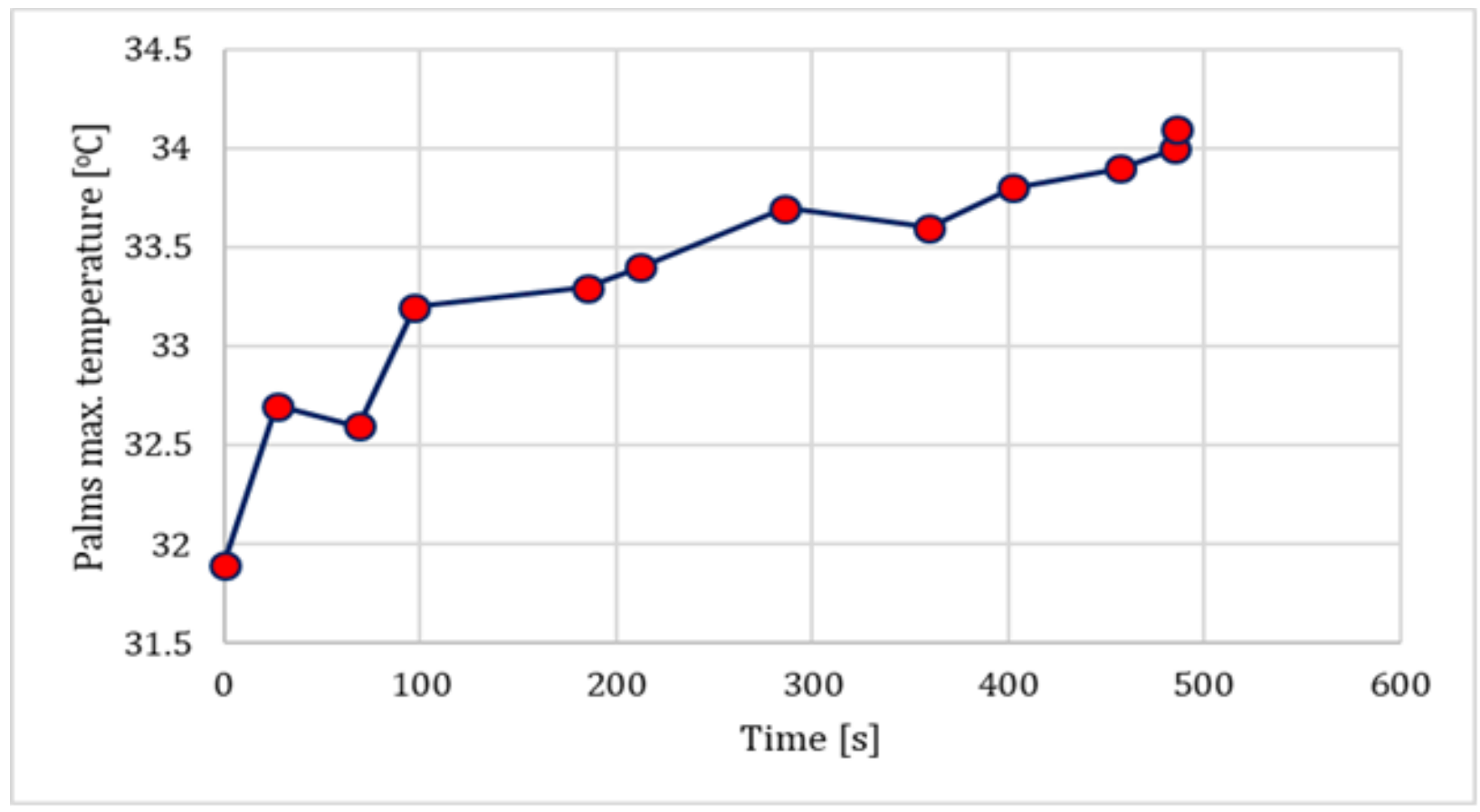

Figure 2. The palms maximum temperature variation of the subject in time recorded by means of the Global Thermo vision Camera, 2019 (The article's first author)

Source: Authors' own research.

Since there are periods of time with a decreasing temperature, it signifies that a part of the energy was sent to the exterior. With the special contribution of the subject, the energy beams sent to the exterior to another person can increase in intensity. Associated with good thoughts they can heal the other person. Associated with bad thoughts they can sicken the other person. The concrete results of this experiment justify the activity of the bio-energy healers whose results are difficult to register and to quantify. 
The second type of investigation was made using the Bio Chips Doctor Tech and a Bio Well device to record the results. The Bio Chips are the invention of our researchers from the "Iustin Capră" association. They have received many international appreciations (Travel cushion, 2019; Biocip kit, 2019; Medical bracelet, 2019; Velcea et al., 2017; Velcea et al., 2019; Mândrea et al., 2019). The Bio Chips are passive devices which are activated by the energetic misbalance manifested by a high electric potential of the acupuncture points where they are placed. They begin to work when they are placed on the acupuncture points in misbalance. They stop functioning when the energetic balance is reached. If we let them on the body they will restart their action at the moment of another misbalance apparition. Between the activity periods, a state of waiting is installed.

The Bio Well device presented many times before in our articles (Mândrea \& Curta, 2019; Mândrea et al., 2019; Mândrea et al., 2018; Mândrea \& Chirilă, 2017) is a device used to characterize the health state and also the energy state of a human being (Korotkov, 2002, 2007, 2014, Yakovleva \& Korotkov, 2013).

Two Bio Chips were placed on the subject neck, symmetrically to the vertical axe of the body. The subject, the first author of this article, was measured once before and twice after using the Bio Chips. The results in terms of stress, energy, general body balance and organs balance are presented in Figure 3.

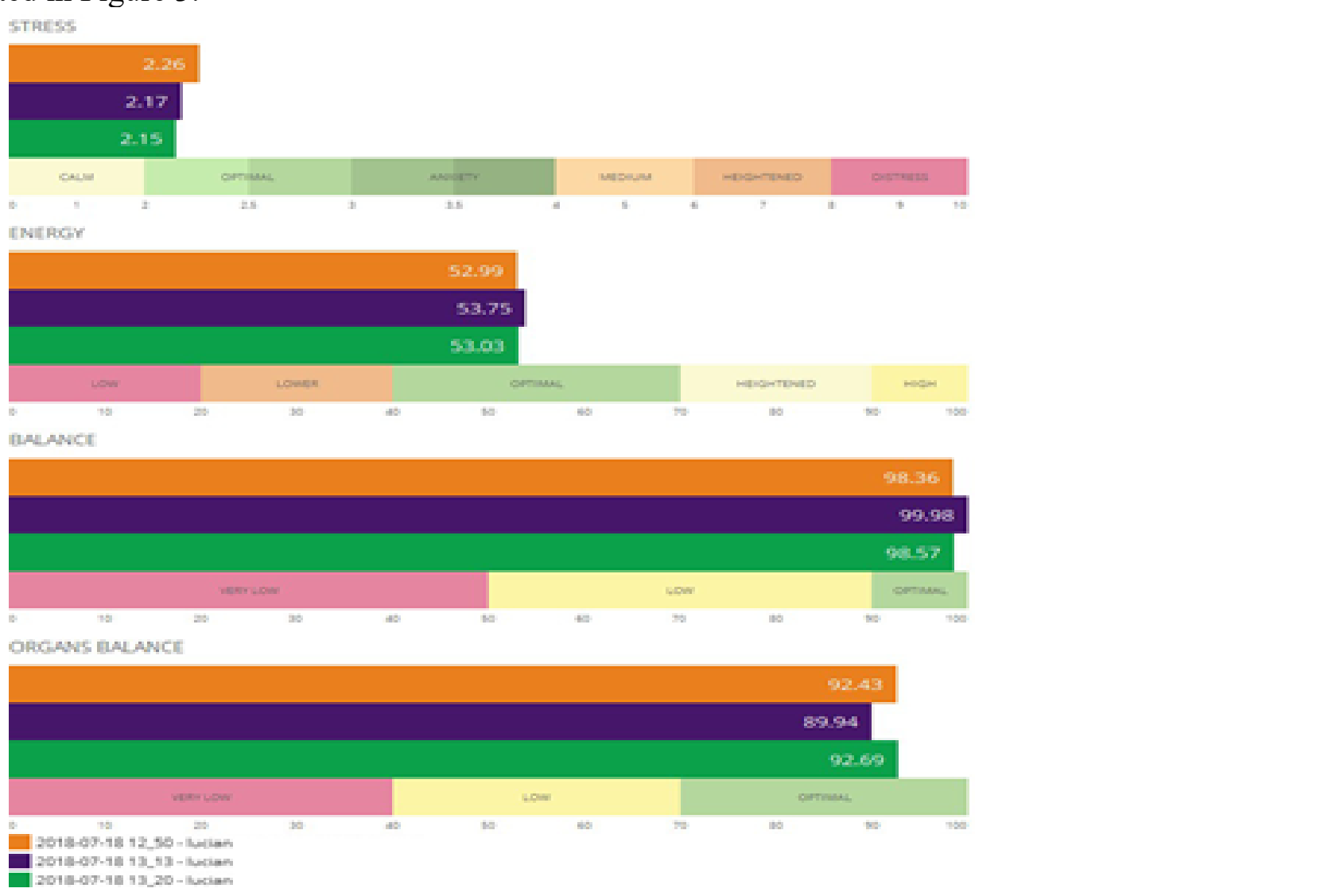

Figure 3. The subject stress, energy and balance for the three measurements. (The article's first author)

Source: Authors' own research. 
As we can see at the second measurement, with parameters characterized by the violet color, after applying the Bio Chips, the stress decreases, the energy increases and the general balance of the body reaches an unbelievable value of $99.98 \%$. At the third measurement showed in Figure 3 with green, all the parameters are improved compared with the first measurement showed with orange. Similar results can be obtained using the Bio Chips on the ears or on insoles inside shoes (Velcea et al., 2017; Velcea et al., 2019; Mândrea et al., 2019). It is preferable to put them on the acupuncture points and if you do not know their positions, you can put them on the zones where you have a pain.

The third type of investigation was made using the Keshe devices. The three devices used are presented in Figure 4, near a pen, just to see their size.

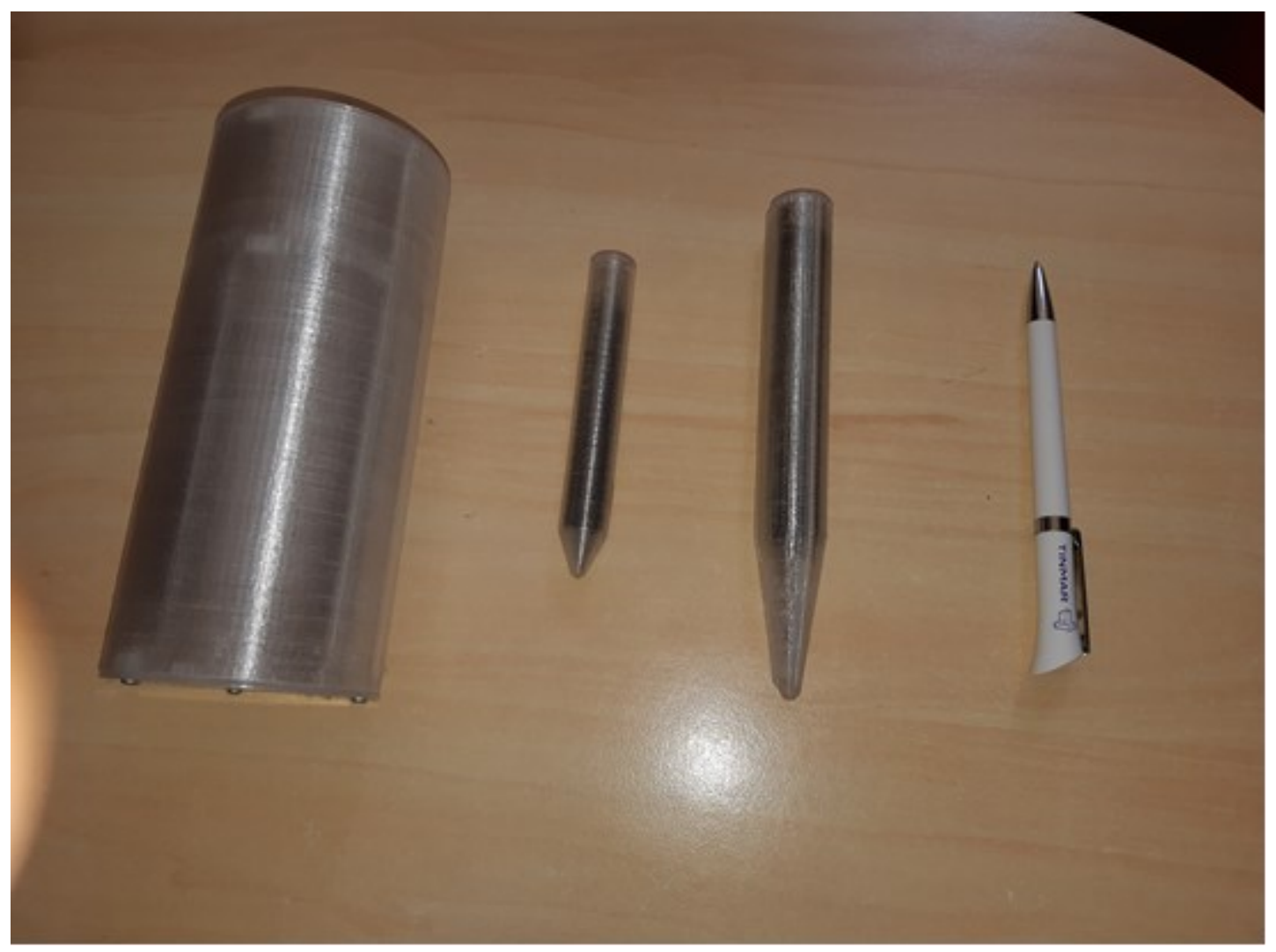

Figure 4. The three Keshe devices with cover made on a 3D printer.

Source: Authors' own research.

From right to left, the first is a Keshe device with air inside. The second, the small one, has $\mathrm{CO}_{2}$ gas inside and the third, the bigger one, is a rotating Keshe device which contains inside three units of the first type. The Keshe devices contain coils which can store energy for short periods of time and then they can release it.

As usual, the subject, the first author of the article, made a reference measurement by means of the Bio Well device to note the initial personal parameters. Then, he exchanged continuously energy with the first Keshe device at the level of the third eye, corresponding with the sixth energy center of the human being. 
The results before and after using the Keshe device in terms of stress, energy and balance can be seen in Figure 5.
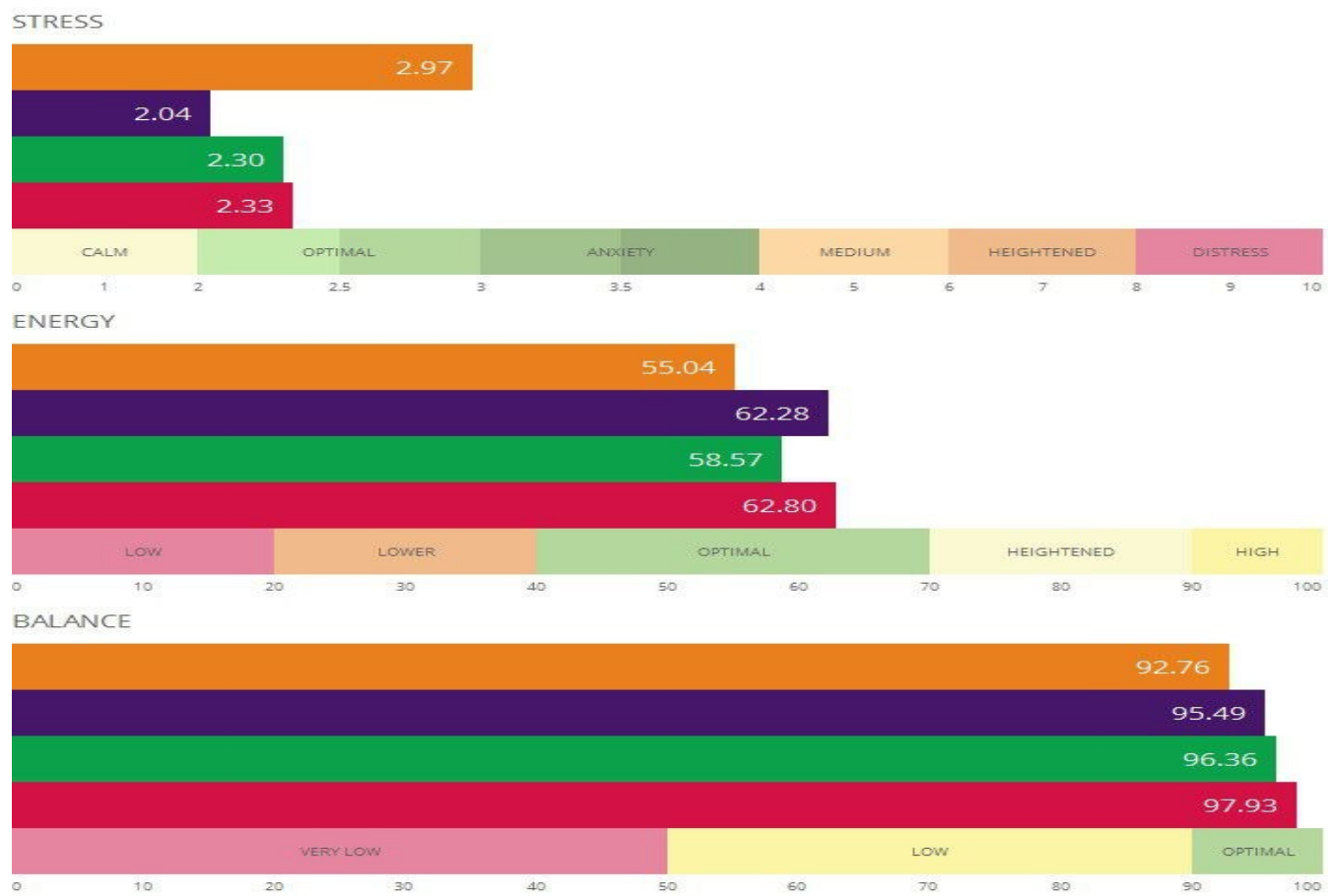

ORGANS BALANCE

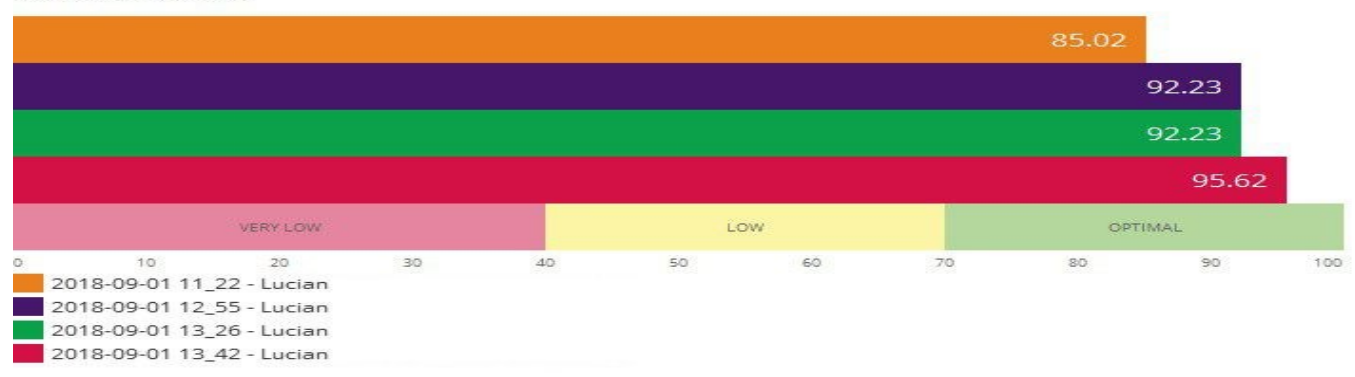

Figure 5. The subject stress, energy and balance for the four measurements with the first Keshe device.

(The article's first author)

Source: Authors' own research

As everyone can see the Keshe device was very efficient from the beginning. At the second measurement represented with violet, the Keshe device was decreasing the stress, was increasing very much the energy and was increasing the general and also the organ balance. At the end of the fourth measurements represented with red, the last three parameters were improved.

The measurements by means of the second Keshe device were also made at the level of the third eye. After the measurements, the alignment of the energy centers was improved with $2 \%$ as we can see in Figure 6. 


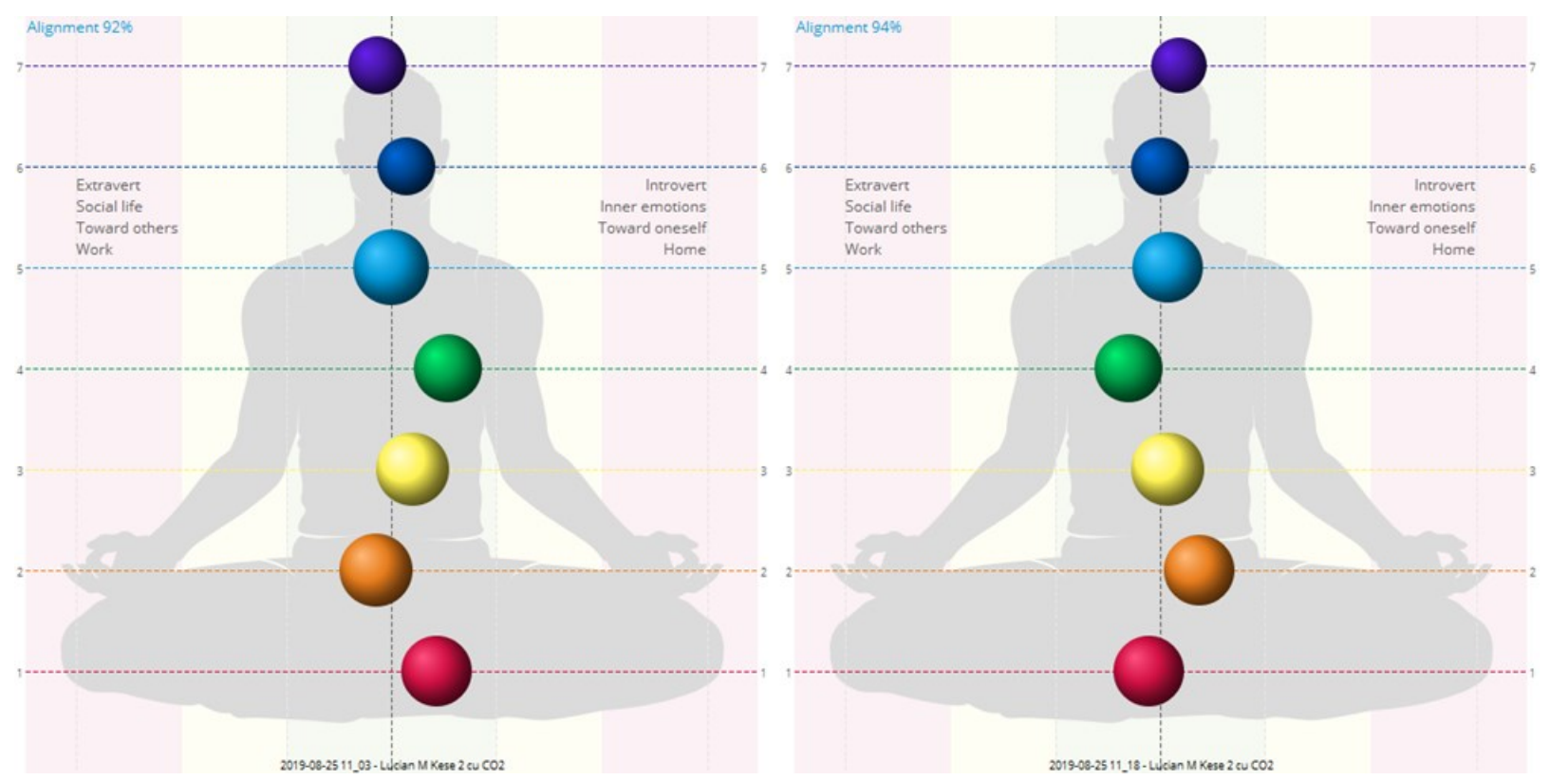

PICBE | 691

Figure 6. The seven energy centers alignment before and after using the second Keshe device

(The article's first author)

Source: Authors' own research

The measurements by means of the third Keshe device were made in principle as before. The precise position of the rotating Keshe device can be seen in Figure 7.

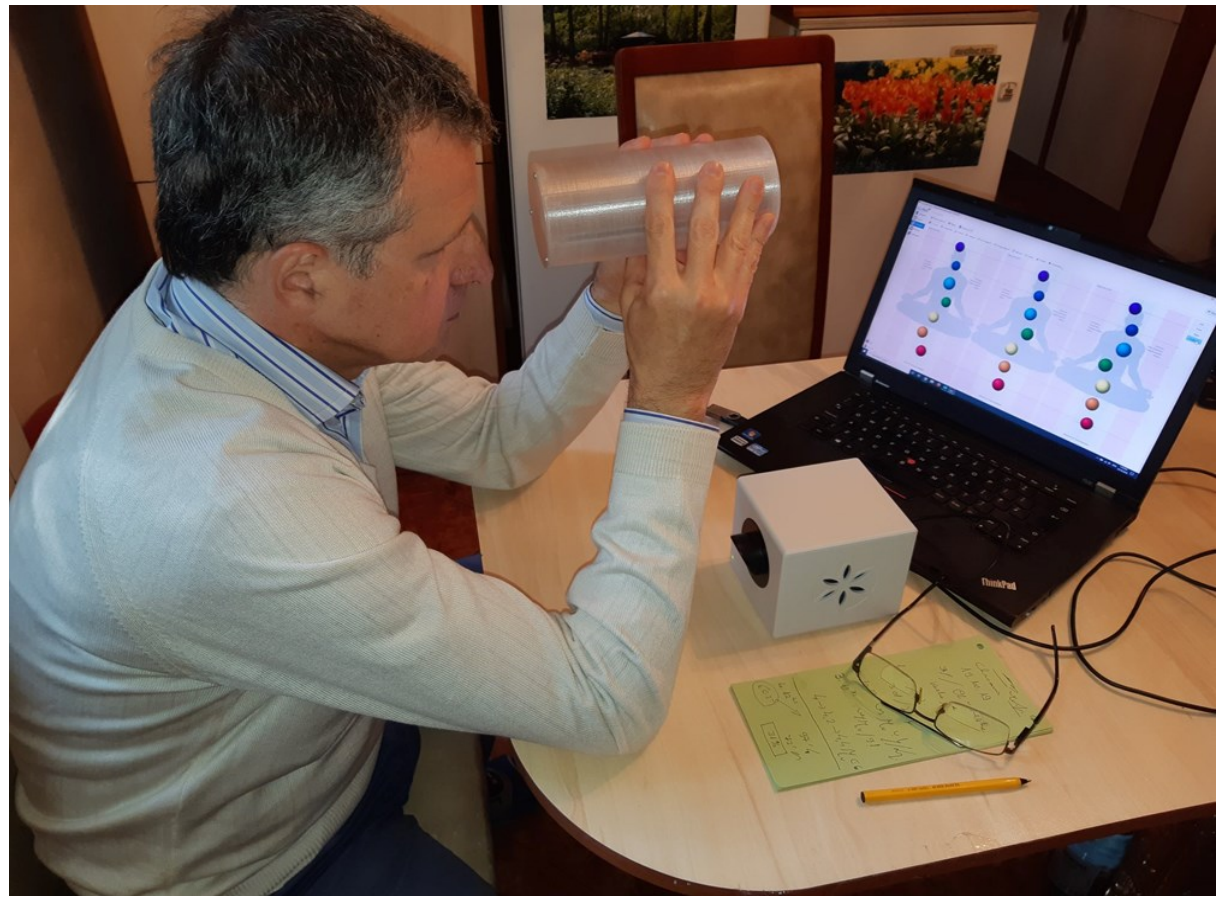

Figure 7. The measurements made by means of the third type of Keshe device. (The article's first author)

Source: Authors' own research 
The results before and after using the third Keshe device in terms of stress, energy and balance can be seen in Figure 8, from orange to green.

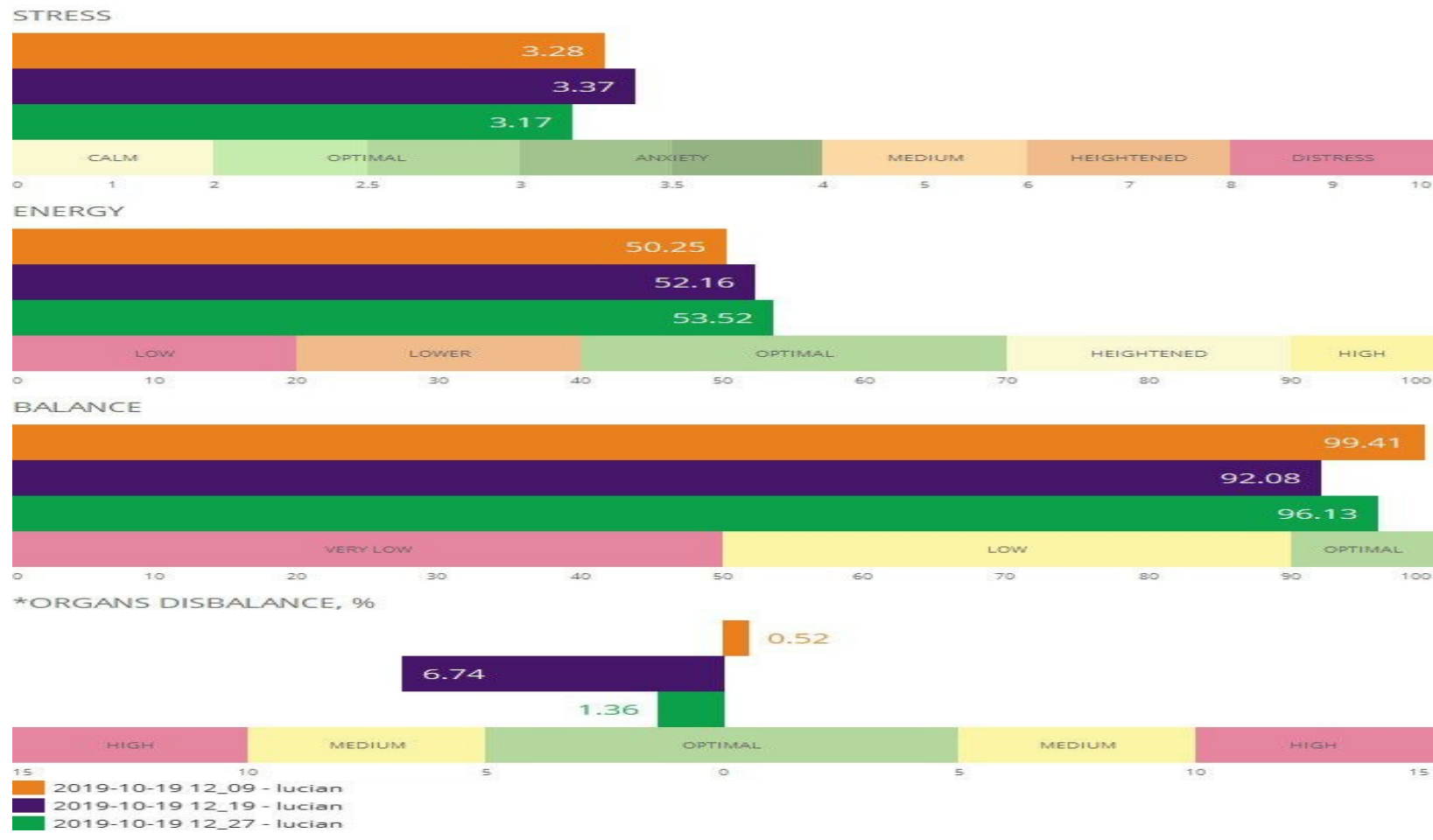

Figure 8. The subject stress, energy and balance for the three measurements with the third Keshe device.

(The article's first author)

Source: Authors' own research

As we can see the subject was more stressed at the beginning because the third Keshe device is a rotating and more powerful one which can give unexpected effects.

The third Keshe device improved only the energy of the subject at the end of the three measurements, the value with green. We can see also that the stress was a little decreased compared with the first measurement with orange.

From the three Keshe devices, the first one was more efficient, maybe also due to its size. Speaking about the more sofisticated one, the third device which contains in fact three devices inside, a more extended study would be useful, using different rotating speeds. For the results from figure 8 , a new soft was used.

\section{Conclusions}

Taking into account the whole complexity of the human being, we consider that our article can be integrated in the approach "The old man, the new man, the smart approach".

The study of the energy shell of the human being was happily much extended during time, many researchers contributing to the actual achievements (Becker \& Selden, 1985; Bevk et al., 
2000; Boyers \& Tiller, 1973; Chiang et al., 2005; Cohen \& Popp, 1997; Cohen \& Popp, 2003; Connor \& Schwartz, 2007; Devaraj et al., 1997; Dobrin et al., 1975; Dobrin et al., 1979; Edwards et al., 1989; Edwards et al., 1990; Inaba et al., 1998; Inaba et al., 2000; Kilner \& Cantab, 1911; Moss \& Johnson, 1973; Rubik, 2004). Some of them refer also to the Kirlian effect, from where many things developed later.

This thing allowed us to use the Bio Well device for the last two parts of our article.

The authors presented three sets of original results which had the purpose to show everybody that using energy in different manners people's health state can be improved and they can be even cured. Using the Bio Well Device, the authors could show that a very high general balance of the human being can be obtained as in the first part of the article. With continuous efforts, this very good equilibrium can be even maintained in time.

The passive devices called by us Bio Chips can be very useful, too, all the time. They cannot harm you because they employ your own energy.

We proved also that the Keshe devices can be used for the wellbeing of the human beings. These devices are also passive devices and can be directed to every point or zone of your body.

We offer our thanks to Mr. Ionuț Baciu, male nurse from Emergencies Medical Unit who constructed and offered us all the three Keshe devices for the experiments. He used the Keshe devices in practice for joints pain, inflammatory processes and abdominal pains.

Everybody can be healed with energy by others or using different devices, as we showed in this article. Energy methods used to heal the others must be considered as an alternative to classical methods. They can also be used as additional methods, in parallel with other methods because the chance to interfere with them is much reduced.

Our new findings reveal very well the complexity of the human being and show that many unbelievable things can still be discovered in the future about ourselves.

\section{References}

Biocip kit set for first help during travel (2019) (Biocip set-trusă de prim ajutor în călătorie).

MEDALIE DE AUR (GOLD MEDAL) la Salonul International de Invenții și Inovații Traian Vuia, Timișoara (International Innovation Salon Traian Vuia), 14 iunie 2019

Diplomă de excelență și medalie din Republica Moldova (Excellence diploma and medal from Republic of Moldova), Salonul International de Invenții și Inovații Traian Vuia, Timișoara (International Innovation Salon Traian Vuia), 14 iunie 2019.

Medical bracelet with energy rebalancing effect (2019) (Bratară medicală cu efect de reechilibrare energetică), MEDALIE DE AUR (GOLD MEDAL) la Salonul International de Invenții și Inovații Traian Vuia, Timișoara (International Innovation Salon Traian Vuia), 14 iunie 2019.

Travel cushion with energy rebalancing effect (2019) (Coussin de voyage a effet de reequilibrage energetique). GOLD MEDAL, Geneve, le 12 avril 2019, SPECIAL AWARD, Taiwan Invention Association, International Exhibition of Inventions, Geneva, 12 May 2019.

DIPLOMA DE MERIT a Ministerului Cercetării și Inovării (MERIT DIPLOMA of the Research and Innovation Ministry), 10-14 aprilie 2019, MEDALIE DE AUR (GOLD MEDAL) la 
Salonul International de Invenții și Inovații Traian Vuia, Timișoara (International Innovation Salon Traian Vuia), 14 iunie 2019.

Becker R. O., Selden G., (1985) The body electric : electromagnetism and the foundation of life, New York City, William Morrow and Company.

Bevk M., Kononenko K., Zrimek T. (2000) Relation between Energetic Diagnoses and DV

Images, From the proceedings of the New Science of Consciousness, Ljublana, Russia, October 2000.

Boyers D. G., Tiller W. A. (1973) Corona discharge photography, Journal of Applied Physics 44:3102.

Chiang Lee H., Wah Khong P., Ghista D. (2005) Bioenergy based medical diagnostic

application based on gas discharge visualization, Conference Proceedings IEEE Eng. Med. Biol. Soc. 2:1533.

Cohen S, Popp F. A. (1997) Bio photon emission of the human body, J. Photochem Photobiol B., Biol. 40:187.

Cohen S, Popp F. A. (2003) Bio photon emission of the human body, Indian J Exp. Biol. 41(5):440.

Connor M., Schwartz G. (2007) Measuring ELF magnetic fields, In Schwartz G, editor:

Research Findings at the University of Arizona Center for Frontier Medicine in Bio field Science: A Summary Report. Available at: http://lach.web.arizona.edu/CFMBS_Report.pdf , Accessed September 2007.

Devaraj B., Usa M., Inaba H. (1997) Bio photons: Ultra weak light emission from living systems, Curr. Opin. Solid State Mater Sci. 2:188.

Dobrin R. et al. (1975) Experimental measurements of the human energy field, In Krippner S., Rubin D., editors: The energies of consciousness, New York City, Gordon and Breach .

Dobrin R. et al. (1979) Experimental measurements of the human energy field, In Krippner S., editor: Psycho-energetic systems: the interface of consciousness, energy, and matter, New York City, Gordon and Breach.

Edwards R. et al. (1989) Light emission from the human body, Complement Med. Res., 3:16.

Edwards R. et al. (1990) Measurements of human bioluminescence, acupuncture, and electro therapeutics, Res. Int. J., 15:85.

Fluke (2013) Ti300 - Thermal Imager - User's Manual, Rev.3 2/17, Fluke ${ }^{\circledR}$ Corporation, September 2013.

Inaba H. (1998) Measurement of ultra-weak bio photonic information, Proc. Inst. Electrostat. Japan 22:245.

Inaba H. (2000) Measurement of bio photons from human body, J Int. Soc. Life Inf. Sci., 18:448.

Kilner W.J., Cantab M.B. (1911) The Human Atmosphere or The Aura Made Visible by the Aid of Chemical Screens, Rebman Company, New York, 362 pg.

Korotkov, K. G. (2002) Human Energy Field, Study with GDV Bio-Electronography, BACKBONE PUBLISHING Co., USA, ISBN 096443119X.

Korotkov, K. G. (2007) Diagnosis and monitoring of the human energy-informational state and analysis of subtle energies, applying Gas Discharge Visualization technique, based on the Kirlian method, Saint-Petersburg Technical University SPIFMO, Russia, http://gdvenergiecoaching.be/wp-content/uploads/2012/05/2007-GDV-Overview-article.pdf. 
Korotkov, K. G. (2014) Energy Fields Electro-Photonic Analysis in Humans and Nature. $2^{\text {nd }}$ Edition, Create Space Independent Publishing Platform, April 21.

Mândrea L., Curta I., Velcea M. (2019) The Favorable Effects of Bio-Chips on the Human Being, The $7^{\text {th }}$ Edition of IEEE International Conference on e-Health and Bioengineering, 21-23 November, Iași, Romania.

Mândrea, L., Curta I., Chirilă, A., Deaconu D. (2019) The Excellence as a Habit, The Thyroid PICBE |695 Repair, The 13th International Conference on Business Excellence, Innovation and Sustainability in a Turbulent Economic Environment, 21-22 March 2019, Bucharest, Romania.

Mândrea, L., Curta I. (2019) New Methods to Increase the Human Balance and Self Control, The 13th International Conference on Business Excellence, Innovation and Sustainability in a Turbulent Economic Environment, 21-22 March 2019, Bucharest, Romania.

Mândrea, L., Curta I., Marosy Z. (2018) High Energy, Increased Balance and Self Control, Necessary Conditions for Performance and a Good Health, The 12-th International Conference on Business Excellence, Innovation and Sustainability in a Turbulent Economic Environment, 22-23 march 2018, Bucharest, Romania.

Mândrea, L., Chirilă, A. (2017) The Complete Human Being, Energy and Soul, the $11^{\text {th }}$ International Conference on Business Excellence, Strategies, Complexity and Energy in Changing Times, 30-31 March 2017, Bucharest, Romania.

Mândrea, L., Chirilă, A. (2017) The Complete Human Being, Energy and Soul, Proceedings of the International Conference on Business Excellence, published by De Gruyter Open, 2017-08-26, DOI: https://doi.org/10.1515/picbe-2017-0046, pp. 427-436, Volume 11, Issue 1, ISSN 2558-9652.

Mândrea L, Curta I. (2017) The Hysteresis Phenomenon in the Human Bio-Energetic Field, THE $10^{\text {th }}$ INTERNATIONAL SYMPOSIUM ON ADVANCED TOPICS IN ELECTRICAL ENGINEERING, March 23-25, 2017, Bucharest, Romania.

Mândrea, L., Curta I. (2017) The Modification of the Energy Level of the Human Being, Influences on the Psychic State and Health, A XVII-a Conferință internațională multidisciplinară "Profesorul Dorin PAVEL - fondatorul hidroenergeticii românești", The $17^{\text {th }}$ International Multidisciplinary Conference "Professor Dorin PAVEL", Sebeș-Alba, 2-3 iunie 2017, pg. 117-124, ISSN 2067-7138.

Mândrea, L., Torp A. (2016) Energia umană și posibilități de remediere proprii, Human Energy and Self Remedy Possibilities, EUB International Conference, April 4-5, Bucharest, Romania.

Mândrea, L., Costea, M., Torp, A. (2015) The Energy Emissions Produced by the Human Being and their Practical Use, THE ${ }^{\text {th }}$ INTERNATIONAL SYMPOSIUM ON ADVANCED TOPICS IN ELECTRICAL ENGINEERING, May 7-9, 2015, Bucharest, Romania, 9781-4799-7514-3/15/\$31.00 C2015 IEEE, P.260-264.

Mândrea, L. (2014) Percepții extrasenzoriale, Sufletul în corpul uman, Extra-sensorial Perceptions, The Soul in the Human Body, Editura Tornada, Tornada Publishing House, Bucharest 2014.

Mândrea, L. (2011) Comportamentul sufletului în corpul uman, The Behaviour of the Soul in the Human Body, Editura Tornada, Tornada Publishing House, Bucharest 2011.

Moss T., Johnson K. (1973) Bio-plasma of Corona Discharge, in S. Krippner, D. Rubin, 
Galaxies of Life: The Human Aura in Acupuncture and Kirlian photography, Gordon and Breach Science Publishers, Inc.

Newton M. (2004) Life Between Lives, Hypnotherapy for Spiritual Regression, Llewellyn Publications, St. Paul, MN 55164 USA.

Newton M. (2006) Destiny of Souls, Daath Book Publishing House.

Rubik B., (2004) Scientific Analysis of the Human Aura. In: In K. Korotkov (ed.): Measuring Energy Fields State of the Science, Fair Lawn, NJ, Backbone, pg. 157-170.

Velcea M., Curta I., Plotog I., Moldovan C., Mândrea L. (2017) Insoles for Drivers, Electrical Vehicles International Conference and Show, ICPE Solar Park, 5-6 October 2017, Bucuresti, Romania.

Velcea M., Mândrea L., Curta I., Ene C. (2019) Efectele favorabile ale utilizării dispozitivelor

Bio-Chips asupra organismului uman, Congresul Internațional de Medicină Integrativă, Ro INMED 2019, București 7-9.11.2019.

Yakovleva, E., Korotkov, K. G. (2013) Electro-Photonic Analysis in Medicine. GDV Bioelectro-graph Research, ISBN 978-1481932981.

Williams, L. (2011). The Survival of the Soul. Hay House, Inc. 